Volume 7 Issue 1, March 2020

Nationally Accredited Journal,

Decree No. B/4130/E5/E5.2.1/2019

\title{
The Position And Function Of Notary In The Using Of State Symbol
}

\author{
Arief Rahman Siregar ${ }^{1}$, Andhika Widya Kurniawan ${ }^{2}$ and Gunarto ${ }^{3}$
}

Abstract. This study tried to answer the problem formulation is What position and Function of Notary in using the State symbol? What if Notaries do malpractices in the using of State Symbol and how sanctions against malpractice Notary Public who use the State Symbol? The purpose of this study to determine the position and Function of Notary in using the State Symbol, and determine sanctions against notaries who do mal practice in the using of State Symbol.

This research was conducted using the normative method, means testing and reviewing secondary data, using literature data in the form of positive law relating to Legislation relating to the issues discussed.

The results of this study concluded that a Notary Public in the office using the Symbol State under Article 16 paragraph (1) letter k of Notary law) and use of the State symbol of Notary's Stamp or Head Letter Position as stipulated in Article 54 paragraph (1) letter j Act No. 24 of 2009 and as Stamp of Department Office as stipulated in Article 54 paragraph (2) letter j Act No. 24 of 2009, while the Notary malpractice in the using of State symbol is not necessarily directly given to criminal sanctions as a form of application of the law ultimum remidium. because there are several steps that must be passed given the Notary has its own rules in the Law on Notary. Notary of the behavior is also governed by a special organization that Indonesian Notary Association (INI), but still asked the criminal responsibility under Act No. 24 of 2009 and Article 154 of the Criminal Code letter if indeed Notary proven legally and convincingly to have malpractice against the using of State Symbol.

Keywords: Notary Authority; Notary Position; Sanctions Against Notary.

\section{Introduction}

Notaries are public officials appointed by the government to assist the public in making authentic act and authority governed by the Act which exist or arise in everyday life. Notary profession is an occupation with specialized skills that require extensive knowledge, as well as a heavy responsibility to serve the public interest and duty of a notary public in writing that regulate legal relations between the parties unanimously enlist the services of a Notary. Notary profession needs to be referred to as behavior that has the following elements:

- Steady moral integrity;

- Must be honest with the client and yourself

- Patience will be the limits of its authority;

- Not solely based on financial interests ${ }^{4}$

According to Article 1 (1) of Notary law (UUJN) states that the notary is a "Public officials authorized to make the certificate is authentic and has more authority as referred to in this Act or under another Act. "General Authorities referred to in Article 1 (1) UUJN

\footnotetext{
${ }^{1}$ Student of Master of Notarial Law, Sultan Agung Islamic University (UNISSULA), Semarang, email: boo rief@yahoo.co.id

${ }^{2}$ Student of Master of Law Program, Faculty of Law, Universitas Islam Sultan Agung email andhika.widya.k@gmail.com

${ }^{3}$ Lecturer of Master of Law, Faculty of Law, UNISSULA, Semarang

${ }^{4}$ Liliana Tedjosaputro, 2003, Etika Profesi dan profesi Hukum, (Semarang: Aneka Ilmu, 2003) p. 93
} 
should be read as public official or notaries who are authorized to make authentic act (Article 15 (1) UUJN) and other authorities referred to in Article 15 paragraph (2) and (3 ) UUJN and serve the public interest. ${ }^{5}$

In Article 1 paragraph 2 of Act No. 24 of 2009 on the Flag, Language, and the State Symbol, and Anthem, it was mentioned that the symbol of the Republic of Indonesia, hereinafter called "Garuda Pancasila"as State Symbol is the motto of Unity in Diversity.

In carrying out his duties, Notary allowed to use the Symbol State "Garuda Pancasila"as stipulated in Article 52 paragraph 1 of Act No. 24 of 2009The products of the notary is a form of authentic deed that has the strength of evidence is perfect, as stated in article 1870 of the Civil Code "One word authentic giving among the parties and their respective heirs, heirs or persons who have the right of them a perfect proof of what is contained therein ". 6

Notary of duty use the State Symbol (Article 16 paragraph (1) letter k Notary law) and the using of State Symbol by a notary for Stamp or Head Letter Position (Article 54 paragraph (1) letter j Act No. 24 of 2009) and as Stamp Service Office (Article 54 paragraph (2) letter j Act No. 24 of 2009).

As a form of exercise of power of the state, received by the notary in the position as Position (not professional), for running such a position, then notary wear coat of arms, namely bird Garuda. With the position as mentioned above, it can be said that the notary running most of state authority in the field of civil law, which is to serve the interests of the people who need proof or legal document form authentic act recognized by the state as a perfect proof.

Every act of government are required to be rooted in legitimate authority. Without any legal authority, an official or a State Administrative Agency can not carry out an act of government. Thus, the legal authority is an attribute for any official or agency. ${ }^{7}$ Every authority given to the position should be based on the legal rule as requiring that positions can work well and do not collide with other positions of authority. Thus if an official (Notary) perform an action beyond the authority that has been determined, it can be categorized as acts of abuse of authority. ${ }^{8}$

Based on the description on the background of the above mentioned problems, then the problems in this study can be formulated as follows: What is the Position and Function of Notary in using the State Symbol?; What if Notary does Malpractices in the using of State Symbol and how sanctions against malpractice Notary Public who use the State Symbol?

\section{Research methods}

This study is a descriptive analysis, means that an analysis of the data based on the theory of common law applied to describe a set of data. ${ }^{9}$ The method used in this research is normative juridical approach to the problems which do formulated by studying the provisions of legislation relating to the issues discussed.

This research was conducted by using materials from the research literature that the data collecting material includes primary law, secondary law and tertiary legal materials.

\footnotetext{
${ }^{5}$ Habib Adjie, 2009, Hukum Notaris Indonesia (Tafsir Tematik Terhadap UU No. 30 Tahun 2004 Tentang Jabatan Notaris), Bandung: PT. Rafika Aditama, p.51

${ }^{6}$ R. Subakti, R Tjitrosudibio, 2008, Kitab Undang-Undang Hukum Perdata, Jakarta: Pradya Paramita, p.475.

${ }^{7}$ Luthfan Hadi Darus, Hukum Notariat dan Tanggung Jawab Jabatan Notaris, p. 7

${ }^{8}$ Habib Adjie, 2007, Sanksi Perdata \& Administratif Terhadap Notaris Sebagai Pejabat Publik, Surabaya: PT Refika Aditama, p. 33.

${ }^{9}$ Bambang Sunggono, Metodologi Penelitian Hukum, PT.Raja Grafindo Persada, Jakarta, p.38
} 
Volume 7 Issue 1, March 2020

Nationally Accredited Journal,

Decree No. B/4130/E5/E5.2.1/2019

\section{Results and Discussion}

\subsection{Position and Function of Notary in Using The State Symbol}

Notaries in his duties and shall be based normatively to the rules of law relating to the actions to be taken and then poured in deed. ${ }^{10}$ Acting pursuant to the applicable law would provide legal certainty to the parties, that the deed made before or by a notary public in accordance with applicable law, so that in case of problems notarial deed can be a guide to the parties. ${ }^{11}$

Social institutions known as "notary" This arises from the requirement in the association fellow human beings who want the evidence to him about the relationship existing civil law and / or going on between them. An institution with assigned by public authority (openbaar gezag) to where and when the law requires such or desired by the community, make written evidence that has authentic power. ${ }^{12}$

Authentic deeds as proof of the strongest and most have an important role in any legal relations in society. In a variety of business relationships, activities in the fields of banking, land, social activities, and others. The need for written evidence in the form of an authentic deed is increasing in line with increasing demand for legal certainty in a variety of economic and social relations, both at the national, regional, and global.

According to Hans Kelsen, the concepts related to the concept of legal liability is the concept of legal responsibility. That someone is legally responsible for an act he or she bears particular responsibility hukum. 38 theory of legal liability is required to be able to explain the relationship between the responsibilities of a notary relating to the authority of the notary based UUJN who are in the field of civil law. The authority is one of them is creating evidence that can provide legal certainty for the parties, then became an offense or act which must be justified by a crime. To criminal liability means in relation to the offense. From the standpoint of pure law, the offense is characterized as a condition of the sanction. ${ }^{13}$

Notaries in running position should pay attention to and subject to the Act No. 30 of 2004 on Notary abbreviated UUJN and Notary Code which are applicable regulations for moral guidance notary profession. Notary authority as an elaboration of Article 1 paragraph 1 UUJN contained in article 15 UUJN.

From the article it can be concluded that the authority of the Notary in addition to making authentic act also assigned to register and certify (waarmerken and legaliseren) ${ }^{14}$ papers / deeds made under the hand and provide advice / information on the law and an explanation of the legislation, especially with regard to the contents of the deed by the parties before the Notary.

\footnotetext{
${ }^{10}$ Susanto, R., 2002, Tugas, Kewajiban dan Hak-hak Notaris, Wakil Notaris, Jakarta: Pradnya Paramita, p.56.

11 Otodisoerjo, R. Soegondo, 2003, Hukum Notariat di Indonesia (Suatu Penjelasan), Second Printed, Jakarta: Raja Grafindo Persada, p 49.

${ }^{12}$ GHS. Lumban Tobing, 2006, Peraturan Jabatan Notaris, Jakarta: Erlangga, p.2.

${ }^{13}$ Hans Kelsen (Interpretation by Somardi), 2007, General Theory Of Law and State,Teori Umum Hukum dan Negara, Dasar-dasar IImu Hukum Normatif Sebagai Ilmu Hukum Deskriptif-Empirik, Jakarta: BEE Media Indonesia, 2007, p. 81.

${ }_{14}$ Waarmerking, which posted the letters under the hand by enrolling in a special book, while Legalization is to validate signatures and set a firm date in the letter under the hand by enrolling in a special book, (distinguishing between legalization with photocopies compatibility validation with the original letter).
} 
Notary as a public official as a notary appointed and dismissed by the government authority and given the authority and the obligation to serve the public (public interest) in certain respects, therefore, notaries participate in implementing government authority. As a form of exercise of power of the state, which is received by the notary in the position as Position (not professional), because running the office as it is, the notary put on the state symbol, the eagle as stipulated in Article 16 paragraph (1) letter k Notary law and use of the State symbol of Notary's stamp or letterhead Position as stipulated in Article 54 paragraph (1) letter j Act No. 24 of 2009 and as Stamp of Department Office as stipulated in Article 54 paragraph (2) letter j Act No. 24, 2009. With positions as mentioned above, it can be said that the notary running most of state authority in the field of civil law, namely to serve the interests of the people who need proof or legal document form authentic act recognized by the state as a perfect proof.

From the definitions and the notary's authority is clear that the product made by a notary deed is an authentic documentation tool and full. In order for the deed for its intended function as a means of authentic evidence of the deed should be proven authenticity, so that the deed legally able to guarantee legal certainty. To that should be in a deed must comply with the manufacturing and the requirements specified by law, both formal and material that it does not conflict with the law.

\subsection{Sanctions Against Notary Which Did Malpractice in The Using of State Symbol}

One example of abuse is when a "Garuda" as Symbol State by Notary use for gift or souvenir party private events. It is clearly not appropriate and violate the rules, because the Notary was not in a position of authority to use the State Symbol of Garuda. The act also dishonoring and uphold the dignity and the dignity of the Notary office, as stipulated in Article 3 (2) Notary Code. Notary who mis use the State Symbol is not necessarily directly given to criminal sanctions as a form of application of the law ultimum remidium. In addition, there are several steps that must be passed given the Notary has its own rules in UUJN. Notary of the behavior is also governed by a special organization that Indonesian Notary Association (INI).

Article 8 through Article 10 UUJN governing the various stops Notary. The first is the Notary's resignation with respect, for example because of death, retirement, or at his own request. Second Notary suspended from their posts. This happens because some cases such as in the process of bankruptcy or postponement of debt repayment, was under guardianship for a while, misconduct, or are serving prison time. However Notary concerned can be restored right after the period of suspension expires (period of suspension up to 6 months). Then the last Notary stopped with disrespect. For example, in a variety of conditions such as declared bankruptcy court ruling that has the force of law that is fixed,

Notary deed abusing symbol of the State as gift or souvenir for a private event party, will be dealt with in stages. Starting from the call, inspections, warning verbally, in writing, to a dishonorable discharge proposed by the Board of Trustees in UUJN to the Minister of Justice and Human Rights. The same penalty applied by the Board of the Notary Code of Honor. Apart from the rules governing the office of the Notary profession, a notary who has met the elements of criminal misuse of State Symbol of Garuda, still requested to criminal liability under the Act No. 24 of 2009. Looking at the rules relating to the dismissal of the Notary with no respect Article 13 UUJN states when Notary dishonorably discharged by the minister because sentenced to imprisonment by a court decision which has had permanent legal force, where the Notary is said to have done a criminal act 
punishable by imprisonment 5 (five) years or more. Article 13 The governing UUJN dishonorable discharge for notaries who was sentenced to imprisonment for a period of 5 (five) years or more. With the existence of such provision, the Notary been sentenced less than 5 (five) years, it is still possible to keep carrying out his profession. Wherein the Notary said to have committed a criminal act punishable by imprisonment of five (5) years or more. Article 13 The governing UUJN dishonorable discharge for notaries who was sentenced to imprisonment for a period of 5 (five) years or more. With the existence of such provision, the Notary been sentenced less than 5 (five) years, it is still possible to keep carrying out his profession. Wherein the Notary said to have committed a criminal act punishable by imprisonment of five (5) years or more. Article 13 The governing UUJN dishonorable discharge for notaries who was sentenced to imprisonment for a period of 5 (five) years or more. With the existence of such provision, the Notary been sentenced less than 5 (five) years, it is still possible to keep carrying out his profession. ${ }^{15}$

Prohibitions and criminal provisions had previously been regulated in article 154a of the Criminal Code, which reads, "He who desecrate the flag of the Republic of Indonesia and the symbol kebangsaab the Republic of Indonesia, is threatened with a maximum imprisonment of four years or a maximum fine of forty-five thousand rupiah."

According to the authors that, imposition of sanctions for contempt of the State Symbol maximum is not enough, this is due to the unclear category insult to coat of arms, as well as the sanctions provided only limited when people commit crimes against the state symbol should be met with criminal sanctions. The meaning is type of sanction granted when viewed from the aspect of its objectives more directed at "prevention so that people do not commit crimes," not aiming at "preventing them from committing crimes", and is not meant to "prevent a crime that did not happen."

\section{Closing}

\subsection{Conclusion}

- Notary of duty use the State Symbol (Article 16 paragraph (1) letter k Notary law) and the using of State Symbol by a notary for Stamp or Head Letter Position (Article 54 paragraph (1) letter j Act No. 24 of 2009) and as Stamp Service Office (Article 54 paragraph (2) letter $\mathrm{j}$ Act No. 24 of 2009). Under the provisions of Article 54 paragraph (1) letter $\mathrm{j}$ and as Article 54 paragraph (2) letter j Act No. 24 of 2009, the using of State Symbol of Notary limited to Stamp or Head Letter Position, and Stamp of Department Office (Notary) only,

- Sanctions against Notary malpractice use the State Symbol is not necessarily directly given to criminal sanctions as a form of law enforcement ultimum remidium. because there are several steps that must be passed given the Notary has its own rules in the Law on Notary. Notary of the behavior is also governed by a special organization that Indonesian Notary Association (INI) and still require criminal responsibility under Act No. 24/2009 and Article 154 of the Criminal Code letter.

\subsection{Suggestion}

- Use of Symbol State that does not comply with its designation as stipulated in Act No. 2 of 2014 and Act No. 24 of 2009 must be stopped so that a Notary is not exposed to

\footnotetext{
${ }^{15}$ https://irmadevita.com
} 
administrative sanctions such as dismissal without respect or criminal sanctions as provided in the Act No. 24 of 2009 and Article 154 of the Criminal Code letter.

- Even if a Notary want to specify positions Notary with any other office, for example PPAT on the docket Notary or letterhead, do not need to list the State Symbol and do not need to use the stamp Symbol State, if it still wants to use the stamp to create and use stamps that are not loading the State Symbol.

\section{References}

[1] A Andi Prajitno, 2010, Pengetahuan Praktis Tentang Apa dan Siapa Notaris di Indonesia, Son Media Nusantara, Surabaya.

[2] AA Oka Mahendra, disharmony Regulation Legislation, in ditjenpp.kemenkumham.go.id/htn-dan-puu/422harmonisasi-peraturan-perundang-undangan.html access March 28, 2018

[3] GHS Lumban Tobing, 1999, Peraturan Jabatan Notaris (Notaris Reglement), publisher, Jakarta.

[4] Habib Adjie, 2009, Hukum Notaris Indonesia (Tafsir Tematik Terhadap UU No. 30 Tahun 2004 Tentang Jabatan Notaris), PT. Rafika Aditama, Bandung

[5] Habib Adjie, 2015, Penafsiran Tematik Hukum Notaris di Indonesia berdasarkan Undang-Undang Nomor 2 Tahun 2014 tentang perubahan Atas Undang-Undang Nomor 30 Tahun 2004 Tentang Jabatan Notaris, PT Refika Aditam, Bandung.

[6] Habib Adjie, 2007, Sanksi Perdata \& Administratif Terhadap Notaris Sebagai Pejabat Publik, PT Refika Aditama Surabaya

[7] Habib Adjie, 2009, Sekilas Dunia Notaris Dan PPAT Indonesia, Mandar CV Maju, Bandung.

[8] Hartanti Sulihandari, 2013, Nisya Rifani, Prinsip-Prinsip Dasar Profesi Notaris, Intelligent World, East Jakarta.

[9] Herlien Boediono, 2013, Kumpulan Tulisan Hukum Perdata di Bidang Kenotariatan Buku Kedua, Citra Aditya Bakti, Bandung.

[10] Letezia Tobing, On Principle Lex Specialis, in http://www.hukumonline.com/klinik/detail/lt509fb7e13bd25/mengenai-asas-lexderogat-legi-specialist-generalist, access October 31, 2018

[11] Liliana Tedjosaputro, 2003, Etika Profesi dan profesi Hukum, Aneka Ilmu, Semarang.

[12] Luthfan Hadi Darus, 2017, Hukum Notariat dan Tanggung Jawab Jabatan Notaris, UII Press, Yogyakarta.

[13] MU Sembiring, 1997, Tehnik Pembuatan Akta, Notary Specialist Education Program Faculty of Law, University of North Sumatra.

[14] R. Subakti, R Tjitrosudibio, 2008, Kitab Undang-Undang Hukum Perdata, Pradya Paramita, Jakarta

[15] Shinta Agustina, 2013, Implementasi Asas Lex Specialis Derogat Legi Generali Dalam Sistem Peradilan Pidana, Journal of Law, Faculty of Law, University of Andalas,

[16] Tan Thong Kie, 2000, Buku I Studi dan Serba Serbi Praktek Notariat, New Ichtiar Van Hoeve, Jakarta.

[17] Interview with Achmad Adjie Suseno, Notary and PPAT in Cirebon, Cirebon, 4 September 2018 10:00 